\title{
An Overview of Cement production: How "green" and sustainable is the industry?
}

\author{
Johannes H. Potgieter \\ School of Chemical \& Metallurgical Engineering \\ University of the Witwatersrand \\ Private Bag X3, Wits, 2050 \\ Johannesburg, South Africa \\ E-mail: johannes.potgieter@wits.ac.za
}

Received: May 31, 2012 Accepted: June 11, 2012

doi:10.5296/emsd.v1i2.1872 URL: http://dx.doi.org/10.5296/emsd.v1i2.1872

\begin{abstract}
Problem statement: This paper tries to answer the question: Is cement production still a sustainable industry in the $21^{\text {st }}$ century? Approach: It starts off by considering the current status quo and potential alternatives for the production process, right from the raw meal composition stage through to the final application of cement in concrete. Results: In the process alternative raw meal components and energy sources are reviewed in detail. The changes that could and should be made to cement plants and equipment to produce cement more sustainably, as well as different types of other binders that can be used for construction, are discussed. The suitability of the cement production process to destroy wastes and utilize byproducts from other industrial processes, are highlighted and analysed. Alternative methods and equipment to manufacture cement, are summarized and ways to get rid off or convert the released carbon dioxide from the cement manufacturing, are discussed. Conclusions: In the final instance the conclusion is reached that the cement industry, despite proven new technology, equipment and concepts, can do more to respond fast enough and to a sufficient extent to improve the sustainability of their operations substantially and to an acceptable level for the $21^{\text {st }}$ century.
\end{abstract}

Keywords: Carbon dioxide, sustainable, building industry, cement production, waste materials, recycle

\section{Introduction}

Climate change is a topic that is almost daily in the news. It is well established and widely 
believed in society that the major contributor to climate change is the increase in greenhouse gases, which cause an increase in the temperature of planet earth. It is equally well established from many scientific investigations that one of the prime culprits is carbon dioxide, and recent years have seen increasing legislation to try and limit carbon dioxide emissions. Protesters often confront car makers, oil companies, power companies, shipping firms and the airline industry for their contribution to emissions, but one low-profile business which contributes a sizeable portion of $5 \%$ to greenhouse gas emissions has so far escaped attention. That is the cement industry, and as the demand for infrastructure such as houses, schools, roads, dams, sewers, hospitals and a myriad other structures keeps on growing, so will cement production, because it is the key ingredient of concrete used in construction. It is estimated that by 2050 cement plants worldwide will produce in the region of 5 billion tonnes of carbon dioxide, 20 times as much as government has pledged the entire UK will produce by that time [Adam, 2007]. Furthermore, cement production will always release carbon dioxide, because one cannot change the chemistry of the process. So the question arises, how sustainable can cement production be? What are the current technologies available to improve the industry's sustainability, and what needs to be done in future to improve it?

Modern life without cement is impossible to conceive. This inorganic binder acts as the glue for concrete to construct buildings, roads, dams, bridges, and makes modern infrastructure not just possible, but affordable. Furthermore, cement production and the concrete industry where it is ultimately applied and consumed, are important and dynamic sectors of the world economy and in every country. It is responsible for job creation and multiple cascading economic benefits in secondary associated industries and a major contributor to the improvement of living standards all over the world. Concrete is second only to water in terms of its use by mankind [Hanson, 1995]. Its production exceeds that of its closest industrial material rival, steel, by 30 times in terms of volume and 10 times in terms of mass [Hanson, 1995].

Cement-based materials, such as concrete (cement, water and aggregates) and mortars (cement and fine aggregates), are used in incredibly large amounts. This overview will be restricted to Ordinary Portland Cement (OPC) production, unless specifically stated otherwise. It is estimated that in 2009 the concrete production worldwide exceeded 10 billion tons [Meyer, 2009]. Apart from being abundant and relatively inexpensive compared to other materials, cement and concrete works well at room temperature, do not require sophisticated equipment to mix or apply, can be easily shaped and set to a hard and useful form within a few hours.

Despite its popularity and profitability, the cement industry faces many challenges due to environmental concerns and sustainability issues. It is fundamentally an energy intensive operation and not at all environmentally friendly by nature. Furthermore, it consumes large amounts of non-renewable raw materials and generates substantial amounts of carbon dioxide and environmental particulate matter in the process. It is estimated that $5-6 \%$ of all carbon dioxide greenhouse gases generated by human activities originates from cement production [Rodrigues \& Joekes, 2010]. 
In order to minimize the impact of all of the abovementioned issues, it is clear that the cement and construction industry will have to adapt to remain sustainable and in the process adopt a number of innovative and new practices. It should be fairly obvious that a holistic approach is being called for to ensure survival and prosperity for the cement industry in future, and that it is unlikely that simply addressing one or a few of the challenges ahead will accomplish long term sustainability. This paper will give an overview of a number of areas where improvements have already been accomplished and which, if considered and applied collectively, can contribute substantially to long term sustainability in the cement industry. In the discussion to follow new manufacturing technology, combinations thereof, alternative raw materials and energy sources, alternative binders, as well as ways to deal with emissions, will all be discussed and "best practice" applications highlighted. This paper will contribute to the field by highlighting new developments in process modification for pollution prevention, reviewing the production and employment of alternative binders, raw materials and waste fuel usages, and comparing ways to reduce green house gas emissions. While sustainability incorporates a number of aspects and is certainly not limited to greenhouse gas emissions only, this paper will in the final instance attempt to answer the question: Is cement and concrete production sustainable on a long term basis in terms of carbon dioxide emissions, and are cement producers doing enough to pursue sustainability with reference to reducing, re-using and recycling to ensure the lowest possible emissions of particularly carbon dioxide?

\section{Raw Materials}

Cement is basically produced from burning a mixture of calcerous and silicious material with smaller amounts of alumina $\left(\mathrm{Al}_{2} \mathrm{O}_{3}\right)$ and iron oxide $\left(\mathrm{Fe}_{2} \mathrm{O}_{3}\right)$ (combined as the raw meal) together at high temperature [Potgieter, 1997]. Table 1 gives a summary of the top ten cement producing countries in the world. Not surprisingly, and as is so often the case nowadays, China dominates the picture and produces almost half of the world's cement, with India second. This is in large part due to the urbanization and growth of cities in these Far East countries [Shen et al., 2005].

Table 1. Cement production for major countries in the world in the period 2004-2007 (thousand metric tons) (Rodrigues and Joekes, 2010)

\begin{tabular}{|l|r|r|r|r|}
\hline \multicolumn{1}{|c|}{ Country } & \multicolumn{1}{c|}{$\mathbf{2 0 0 4}$} & \multicolumn{1}{c|}{$\mathbf{2 0 0 5}$} & \multicolumn{1}{c|}{$\mathbf{2 0 0 6}$} & \multicolumn{1}{c|}{$\mathbf{2 0 0 7}$} \\
\hline China & 934000 & 1040000 & 1200000 & 1350000 \\
\hline India(estimated) & 125000 & 145000 & 155000 & 170000 \\
\hline USA & 99000 & 101000 & 99700 & 96500 \\
\hline Japan & 67400 & 69600 & 69900 & 67700 \\
\hline Russia & 43000 & 48700 & 54700 & 59900 \\
\hline Korea & 53900 & 51400 & 55000 & 57000 \\
\hline Spain & 46800 & 50300 & 54000 & 54500 \\
\hline Turkey & 38000 & 42800 & 47500 & 49500 \\
\hline Italy & 38000 & 46400 & 43200 & 47500 \\
\hline Brazil & 38000 & 36700 & 39500 & 46400 \\
\hline World (rest)(estimated) & 2130000 & 2310000 & 2550000 & 2770000 \\
\hline
\end{tabular}




\section{Macrothink}

Therefore, in view of the abovementioned figures, it is obvious that alternative raw material sources, innovative quarrying methods and less energy intensive milling/mixing of the raw meal ingredients could all play a part in conserving raw material reserves and energy.

\subsection{Alternative Raw Material Sources}

One possible way to increase sustainability in cement production, is to use alternative raw materials from those currently employed. One such candidate is fly ash, which has reportedly been tried as a source of silica and alumina needed in the cement manufacturing process [Canpolat et al., 2004; Sahu and Majling, 1994]. Another option is to revisit a previously proven German concept of using gypsum, especially some of the industrial byproduct gypsums, as starting material to simultaneously manufacture sulphuric acid and cement [Anonymous, 1996]. It seems theoretically possible to combine this process with the concept of using fly ash as the other ingredient required and make two useful industrial products from industrial byproducts.

The use of fluxes to lower melting temperature is a well known concept in pyrometallurgy. It has also previously been applied in cement making, and the use of calcium sulphate (gypsum), feldspar and a combination of the these have been reported in literature [El-Didamony et al., 2010; Kwon et al., 2006; Helmy, 2003; Darweesh, 2001; Wirsching, 1978] as a means to reduce the production temperature of OPC (ordinary Portland Cement) by between 150-200 ${ }^{\circ} \mathrm{C}$. This practice has the potential to significantly contribute to lower energy consumption and improved sustainability in OPC production. Sadly, it seems not to be practiced very widely in the cement industry.

\section{- $\quad 2.2$ New/Different Quarrying Methods}

All cement plants rely on quarries supplying their basic raw ingredients for cement production. More effective explosives and new quarrying methods can therefore, at least theoretically, contribute to increased sustainability in the process of making OPC.

\subsection{Better /Newer /Different Mills}

While electrical energy is but one (and a smaller) part of the total energy consumption on a cement plant, the data in Table 2 indicate that the milling of raw meal components and final grinding of clinker and gypsum in the finishing mill, can account for more than $50 \%$ of a cement plant's electricity consumption [Thiesen, 1993; Kohlhaas \& Laban, 1983]. The most commonly used mills are ball mills, but fortunately a newer generation in the form of high grinding efficiency roller mills and HORO mills (pressure mills) are available nowadays that can increase grinding efficiency and lower energy consumption. 
Table 2. Electrical energy consumption processes within a cement plant (Stoiber, 2003)

\begin{tabular}{|l|l|l|}
\hline CONSUMER & ENERGY DEMAND (kWh/t) & \% \\
\hline Extraction \& Blending & 5.5 & 5 \\
\hline Raw material grinding & 26.4 & 24 \\
\hline Raw meal homogenization & 6.6 & 6 \\
\hline Clinker production & 24.2 & 22 \\
\hline Cement grinding & 41.8 & 38 \\
\hline Conveying, packing \& etc & 5.5 & 5 \\
\hline TOTAL & 110 & 100 \\
\hline
\end{tabular}

Generally, the specific power consumption in ball mills is $25-35 \mathrm{kWh} / \mathrm{t}$ when grinding the cement to a fineness of $3500 \mathrm{~g} / \mathrm{cm}^{2}$. According to Alsop et al. (2001), specific power consumption for clinker grinding can be reduced by $20 \%$ if pre-grinding of material can be done first. This usually takes place in a roller press mill. The combination of these grinding techniques has the advantage of avoiding two adverse effects, namely an increase in the water demand of the cement and the possibility of an unacceptable reduction in the initial setting time (Bye, 1999). The energy demand in the ball mills can also be reduced if they are equipped with a high efficiency classifier (Stoiber, 2003).

Energy utilization during the grinding process of clinker and gypsum can also be improved by adding polar organic compounds to the charge in the mill. Because of their highly polar nature, grinding aid compounds preferentially adsorb on surface of ground materials and neutralize forces, which cause agglomeration of the newly produced cement particles. The resultant dry dispersion of cement increases fluidity and reduces mill retention time (Jeknavorian et al. 1998). Furthermore, one of the popular grinding aids, i.e. triethanolamine, is also known to increase the strength of the concrete in which the cement is used. With the consumption of electric energy per unit time held constant during the application of grinding aids, the capacity of the mill is increased, resulting in more efficient consumption of energy, reduced grinding costs and less energy consumption. This practice is nowadays widely employed by cement manufacturers.

\section{Use of Industrial Byproducts and Wastes}

Probably the most lucrative financial practice and source of improved sustainability of the cement and concrete industry, is the practice to use industrial byproducts and wastes in the production process. Not only does it lower costs, but it contributes substantially to lower carbon dioxide emissions per ton of cement produced. The unique fact that the cement 
production process is a high temperature process that can destroy certain types of waste, while in some cases encapsulating the resultant non-destructable portion safely in the final product, has lead to a variety of ways in which several wastes and industrial byproducts can be used as part of the final cement product or production process.

\subsection{Wastes}

The high temperature and oxidative environment in a clinker kiln is ideally suited to destroy a variety of organic wastes. These can range from solid polymer (plastic) type wastes or tyres, to municipal solid or industrial solid wastes and waste solvents or oils, in some cases even CFCs (chlorofluorocarbons) [Tamas, 1992(21); Auber, 1981(22); Weitzman, 1983(23); Mourninghan et al., 1985(24); Sutho et al., 1996(25); Uchikawa \& Obana, 1995(26); Mullick, 1992(27); Potgieter et al., 2002(28)]. It is becoming increasingly important worldwide to destroy old or no longer useful tyres in cement kilns, were they can provide an additional source of energy to replace conventional coal, oil or gas. In the process zinc and vanadium gets incorporated into the resultant clinker [Tamas, 1992]. Provided that the process is properly controlled, the performance of the resultant clinker is not compromised at all [Bolio-Arceo \& Glasser, 1998; Murat \& Sorrentino, 1996].

Solid consumer polymer wastes (non-biodegradable plastic) are another popular source of alternative fuel in cement plants. While there is a danger that dioxins might occur if the destruction is incomplete, especially with chlorinated plastics [Shibamoto et al., 2007], the complete oxidation of such organic wastes leaves just water and carbon dioxide as combustion residues. In such cases careful monitoring of stack outlets are of crucial importance to ensure that no environmental damage is caused by the emissions from the process.

Municipal solid wastes are being increasingly used in the cement production process [Stavraki et al., 2005]. This is not only a good way of getting rid of it, they can also provide some energy to the kiln during the burning thereof. The major concern in the use of municipal solid wastes in the process, is potential release of heavy metals that can get volatilized. Once again the importance of careful monitoring cannot be overemphasized. In addition, certain changes to the design of off-gas handling equipment might be necessary, e.g. baghouses or additional filters before outlet gases are released into the stack [Stavraki et al., 2005]. Not all the heavy metals are necessarily volatilized, some simply get incorporated and encapsulated in the raw meal and resulting clinker. The volume is so small however, that the resulting cement's performance is not compromised compared to that of normal OPC [Murat \& Sorrentino, 1996; Shirasaka et al., 1996; Kakali et al., 1998].

By far the easiest waste to handle as an additional fuel source, are waste solvents and oils. Cement companies usually erect blending facilities [Flowers \& Linderman, 2003] to ensure that a reasonably homogenous mixture is being pumped into the kiln burners where it can be fully oxidized to carbon dioxide and water. Chlorinated solvents pose the same danger as chlorinated plastics, so it is essential that complete oxidation must take place. 


\subsection{Industrial Byproducts}

(a) Phosphogypsum and other waste gypsums

Gypsum fulfils two functions in the cement manufacturing process. Firstly, it acts as a set controller by reacting with the $\mathrm{C}_{3} \mathrm{~A}$ (tricalcium aluminate) phase in the clinker, and secondly a correct dosage of gypsum ensures optimum strength development in cement [Taylor, 1997]. Usually natural gypsum is preferred for use in the cement industry, but a number of cement companies are also using industrially produced gypsum. A number of industrial processes produce gypsum as a waste product, e.g. titanium dioxide production [Potgieter et al., 2002], fertilizer production [Wisching, 1978] and citric / boric acid manufacturing [Bensted, 1980]. Of all these industrial gypsum wastes, phosphogypsum is the most well-known one and also the one being produced in the largest amounts.

Most of the industrial byproduct gypsums contain impurities that are detrimental to the cement being produced from it. Phosphogypsum in particular contains phosphorous and fluoride compounds that can interfere with and retard cement setting [Potgieter et al., 2003; Potgieter \& Potgieter, 2000]. However, a number of suggested purifying processes have been reported in literature for these industrial byproduct gypsums to be treated and rendered safe for use in the cement production process without compromising the performance of the final product [Potgieter et al., 2003; Potgieter \& Potgieter, 2000; Cotea et al., 1986; Singh et al., 1993; Singh et al., 1984].

Gypsum, in combination with or without feldspar, can also lower the clinkering temperature by acting as a flux in the process [Kacimi et al., 2006]. In this instance it is added to the front end of the process, as part of the raw meal mixture, and not in the final step of producing cement. Furthermore, as referred to elsewhere in this paper, gypsum can be used as one of the ingredients of calcium sulpho-aluminate cements (CSA) to produce a low temperature, alternative cement to OPC.

(b) Fly ash

Fly ash is a byproduct from coal combustion during the power generating process. It is an extremely fine ash formed from the inorganic components of the coal that remains after combustion of the carbonaceous part of the coal. It occurs as a silico-aluminate glass with a spherical appearance and average diameter smaller than $45 \mu \mathrm{m}$ [Bakovic et al., 2006; Kruger, 1999]. It is estimated that worldwide nearly 600 million tons are produced annually [Wang et al., 2008, Yao et al., 2009].

Fly ash undergoes a pozzolanic reaction with alkali activators, e.g. the calcium hydroxide released in the hydration of cement to form cement-like compounds. Furthermore, its spherical nature improves the workability, as well as flowability, of concrete mixtures and decreases the permeability of the concrete produced from it. Fly ash additions to cement products are governed by the European Norm 197 [2000] and several other local standards in many countries around the world. Nowadays it is a standard component of most cements and concretes in varying quantities. Its addition to cement allows a reduction in the total carbon dioxide produced per ton of cementitious product produced. 
Fly ash furthermore has the advantage that it can be used as a partial replacement for clay in the raw meal of cement [Canpolat et al., 2004], which further contributes to a reduction in the quarrying and use of natural resources. As referred to elsewhere in this paper, it also forms an important component of alternative cements and binders such as geopolymers, alkali-activated cements (AAC) and calciumsulphoaluminate cements. Bottom ash produced by power stations can be incorporated into raw meal as one of the silica-alumina components [Canpolat et al., 2004].

(c) GGBFS (granulated ground blast furnace slag)

GGBFS is a byproduct of the steel production industry. Contrary to fly ash, it is a latent hydraulic binder that can develop strength due to the formation of cement-like compounds as a result of its composition that contain compounds similar to those found in cement clinker. It can be further activated with alkali activators, especially calcium hydroxide. GGBFS is usually milled to a finer composition than OPC [Maeng, 1996], and as such it can have several beneficial effects if added to cement or concrete mixtures. Just like fly ash, it can form an ingredient in the raw mix for CSA cements, AACs and geopolymers [Kumar et al., 2010; Mozgwa \& Deja, 2009; Komnitsas \& Zaharaki, 2007]. The usually standards and EU norm 197 also governs the allowable additions of GGBFS to cement, and it can be as high as 70\% [EU Norm 197, 2000].

(d) Silica fume

Silica fume is an extremely fine spherical residue from the silicon smelting industry [Toutanji et al., 2004]. Similar to fly ash, it is a pozzolan that can be activated with calcium hydroxide and other alkali activators to form cement-like hydrates that can contribute to the strength of concrete mixtures. As a waste product, its addition to concrete lowers the carbon dioxide equivalent tonnage of production compared to pure OPC alone in the mix. Silica fume displays a physical packing effect in addition to its chemical compound formation contribution in the strength development of concrete mixtures, and is therefore an essential component of high strength concretes. It is usually used in conjunction with a superplasticiser and is often a component of self-leveling concrete.

(e) Metakaolin

Kaolin is a clay, and is normally used for the production of chinaware. However, when it is heated to approximately $800{ }^{\circ} \mathrm{C}$, it becomes activated and as metakaolin it possesses pozzolanic properties. Although it requires heat to produce, metakaolin additions to cement can increase its strength substantially [Curcio et al., 1998; De Silva and Glasser, 1992; Potgieter-Vermaak and Potgieter, 2006]. It has been reported in literature that up to $30 \%$ of OPC can be replaced by an equivalent amount of metakoalin produced at a much lower temperature and without any carbon dioxide release in the process, while at the same time achieving a substantial increase in the cementitious mixture's strength.

(f) Red Mud

The accident at the alumina plant near Kolontár in Hungary in October 2010, when 
approximately one million cubic meters of red mud were accidentally released into the surrounding countryside, once again draw the attention to the problems associated with this and many other types of solid industrial waste products. Red mud is a by-product waste of the Bayer process, which is the main industrial means of refining bauxite in order to obtain alumina. This alumina is then used as raw material to produce aluminium through electrolysis of alumina by the Hall-Héroult process [Schmitz, 2006; Chandra, 1996]. Red mud consists of a mixture of solid and metallic oxide-bearing impurities, which includes oxidised iron(the source of the red colour), silica, unleached residual aluminium, and titanium oxide. One of the major disposal problems of red mud is the energy required to dry it. One possible solution is to use waste heat (e.g. from a cement kiln) to dry this waste. However, it can act as an ideal raw meal component in the cement making process if the handling problems can be overcome, as it contains many of the essential raw meal element required for clinker production. However, a necessary condition for the use of red mud is that the sodium hydroxide it contains should be removed to an acceptable level $(<0.5 \%)$.

\subsection{Concrete}

Industrial wastes and byproducts are not only added to cement, but also to concrete mixes produced from it. Apart from the usual fly ash, blast furnace slag, metakaolin and silica fume already mentioned above, a number of other wastes can be utilized in concrete to lower the amount of either cement or aggregates use. Typical examples include the recycling of building and demolition debris as coarse aggregates in concrete [Marinkovic et al., 2010; Corinaldesi, 2010] and glass cullets [Rajabipour et al., 2010; Idir et al., 2010]. Organic admixtures in the form of water-reducers to reduce the amount of cement used in a concrete mixture [Li et al., 2005; Jolicoeur \& Simard, 1998], superplasticers to increase pumpability and the design of self-leveling concrete [Djelal et al., 2002; Leeman \& Winnefeld, 2007] to reduce the need for vibration of concrete in formwork are all examples of how energy usage associated with construction can be further reduced.

\subsection{Energy Efficiency}

The addition of industrial byproducts and wastes to cement in the manufacturing process or to concrete mixtures, essentially improves the overall energy balance and efficiency of the production process. However, it is not the only way in which energy efficiency can be improved. Over the decades the cement manufacturing process has changed from one using a slurry process to mix the raw meal ingredients, to a totally dry process in the modern plants. Furthermore, the addition of pre-heaters to the older, long kilns has increased heat recovery and caused an increase in production capacity. This all has lead to the decrease in the energy required for the production of cement from around $5700 \mathrm{~kJ} / \mathrm{kg}$ in the old wet processes to 3 100 kJ/kg-3 600 kJ/kg in modern plants [Zur Strassen, 1957; Johansen \& Kouznetsova, 1992; Popescu et al., 2003]. This in itself has made a huge contribution to the sustainability of cement production. Nowadays up to 6 pre-heaters and a pre-calciner are considered standard equipment in a modern cement plant.

Another modern development in improving energy efficacy, is the practice of heat recovery to generate electricity. Waste heat from cement kilns have traditionally being used to dry 
either coal and/or raw materials, but since the 1980's various boiler and heat exchanger combinations have been installed at cement plants worldwide to generate steam and subsequently electricity from it. This concept is of course not limited to cement kilns, but is equally widely employed in steel smelters and non-ferrous smelting plants that all have high temperature waste gases coming off at the back end of the process. Some companies advertising on the internet claim that up to $30 \%$ savings can be achieved in the electricity consumption of a cement plant if waste heat recovery systems are installed to generate on-site electricity.

\section{Alternative Cements and Binders}

\subsection{Alkali Activated Cements (AAC)}

Alkali activated cements typically consist of limestone, iron slag, coal fly ash or thermally activated clays, which are then activated by soda ash (alkali carbonate), $\mathrm{NaOH}$, or alkali silicates (water glass). The binder material must contain a reasonable amount of a glassy or amorphous silica phase. AAC typically produce $95 \%$ less $\mathrm{CO}_{2}$ emissions than a similar mass of OPC and is also beneficial from the point that it reduce the impact of other industrial by-products on the environment. Furthermore, these AAC can be cured at room temperature. A number of studies have been reported in literature on their use and production. [Zuda et al., 2010; Green, 2006 and references therein; Palomo et al., 1999; Roy, 1999].

\subsection{Calciumsulphoaluminate (CSA) Cement}

Typically low-grade limestone, bauxite fines, phosphogypsum, fly ash and blast furnace slag, in various proportions, can be utilized to manufacture CSA cement. CSA cements are expansive cements and can be produced at about $1200{ }^{\circ} \mathrm{C}$, which is $200-250{ }^{\circ} \mathrm{C}$ below OPC's production temperature. Furthermore, the fired clinker is relatively soft and friable and is easy to grind. Consequently the manufacturing of CSA cement consumes less energy than OPC [Beretka et al., 1992; Taylor, 1997]. Combinations of CSA cement and OPC can be interground and applied together in construction, as the expansive cement could counter the shrinkage of concrete and mortar on hardening. Care should be taken if any pozzolans are to be used, as the reduced level of calcium hydroxide production during the hydration of the OPC component of such mixtures might not be sufficient to activate the pozzolans.

\subsection{Belite Cement}

One approach to the reduction in energy consumption in the production of cements is to reduce the lime saturation factor (LSF) of the raw feed. The LSF is an indication of how much lime (from the calcined limestone) is consumed in the clinker production through the formation of calcium silicate and calcium aluminate phases. A high quality lime is required to obtain the,typical LSF of between $92-98 \%$ that is usually employed in normal OPC production (Potgieter \& Love, 2010). The substitution by a low lime cement leads to energy saving and also to a reduction of $\mathrm{CO}_{2}$ emission from the decarbonation of the limestone. $\mathrm{A}$ reduction in LSF increases the belite content $\left(\mathrm{C}_{2} \mathrm{~S}\right)$ and decreases the alite content $\left(\mathrm{C}_{3} \mathrm{~S}\right)$ in the clinker produced [Popescu et al., 2003; Sharp et al., 1999; Lawrence, 1998]. This has the advantage that formation of $\mathrm{C}_{2} \mathrm{~S}(65.1 \% \mathrm{CaO})$ occurs at lower temperature than the formation 
of $\mathrm{C}_{3} \mathrm{~S}(73.7 \% \mathrm{CaO})$. When the LSF is reduced to $75 \%$, a virtually alite free clinker is formed. This kind of cement has low aluminium content and its main mineral phase is dicalcium silicate (belite). The reduction of the $\mathrm{CaCO}_{3}$ content reduces the energy demand by $15-20 \%$ for a Lime Saturation Factor of $80-85 \%$ and allows satisfactory clinker formation at $100-150$ ${ }^{\circ} \mathrm{C}$ lower than for OPC production [Popescu et al., 2003]. Further substitution of some natural raw materials by suitable waste materials also leads to a decrease in the energy demand. To produce low energy cement with adequate strength development and LSF below $85 \%$, belite of sufficient reactivity must be produced [Sharp et al., 1999, Lawrence, 1998]. Active forms of dicalcium silicate ( $\mathrm{a}$ ' and $\beta-\mathrm{C}_{2} \mathrm{~S}$ ) in belite clinkers can be achieved by very quick cooling at a rate of at least $500{ }^{\circ} \mathrm{C} / \mathrm{min}$ in the range of $1300-700{ }^{\circ} \mathrm{C}$, or by inclusion of an appropriate mineraliser [Popescu et al., 2003].

\subsection{Geopolymers}

Geopolymers are inorganic polymers consisting of repetitive and alternating $\mathrm{SiO}_{2}$ and $\mathrm{Al}_{2} \mathrm{O}_{3}$ units in an amorphous mass [Davidovits, 1989]. Geopolymers are typically made from a silica-alumina source, such as fly ash, metakaolin, blast furnace slag and a strong alkali activator, such as sodium hydroxide, water glass, potassium hydroxide, sodium sulphate, lime or combinations thereof. It has excellent strength and is often applied for waste stabilization purposes, encapsulation of heavy metals and for refractory purposes [Berger et al., 2009; Duxson et al., 2007 and references therein; Provis et al., 2009; Zhang et al., 2008].

\subsection{MDF Cement}

An interesting composite made from Portland cement is so-called MDF, or macro-defect free cement [Kendall et al., 1983]. MDF can be processed like polymers, and combines cement properties with that of water-soluble polymers, e.g. polyvinyl alcohol (PVC) or poly-acryl amide. When compared to traditional cement-based materials, the properties of MDFs are superior [Santos et al., 1999]. However, when exposed to water, their mechanical properties are severely damaged, and this, among other things, limits their use.

\subsection{Novacem}

A British company, Novacem, has recently come up with a new cement based on the use of magnesium silicates, a group of compounds which mean the cement absorbs atmospheric $\mathrm{CO}_{2}$ during the hardening process. The cement production is based on magnesium oxide $(\mathrm{MgO})$ and hydrated magnesium carbonates. During the production process accelerated carbonation of magnesium silicates takes place under elevated temperature and pressure (i.e. $180{ }^{\circ} \mathrm{C} / 150$ bar) levels. The material produced is then heated at low temperatures $\left(700^{\circ} \mathrm{C}\right)$ to produce $\mathrm{MgO}$, with the $\mathrm{CO}_{2}$ generated being recycled back in the process. The use of magnesium silicates eliminates the $\mathrm{CO}_{2}$ emissions from raw materials processing. In addition, the low temperatures required allow the use of low energy fuels which further reduce carbon emissions. Overall, the production process to make 1 ton of Novacem cement absorbs up to $100 \mathrm{~kg}$ more $\mathrm{CO}_{2}$ than it emits, making it a carbon negative product. [http:///novacem.com, 2010] 


\subsection{Hydraulic Lime}

The hydraulic behavior of this material is related to the clay content of the limestone from which the lime was made, and it has been used since Roman times in building applications [Black et al., 2010]. One of the best examples of the application of hydraulic lime is in the construction of the Eddystone Lighthouse in the UK by Smeaton. Nowadays this material is very popular in the heritage sector, and it is often combined with ground glass cullet and other waste materials in which the lime can induce a pozzolanic reaction to result in C-S-H binding phase. Artificial hydraulic lime can also be synthetically made from a low silica limestone blended with waste materials such as fly ash, burnt shale and glass cullet [Zawawi \& Banfill, 2006].

\subsection{Plaster of Paris}

Plaster of Paris is a building material in the form of a dry powder that, when mixed with water to form a paste, liberates heat and then hardens, similar to mortar or cement [Wischung, 1978]. However, unlike mortar and cement, plaster remains quite soft after setting, and can be easily manipulated with metal tools or even sandpaper. It is based on calcium sulphate hemihydrate, or bassinite, with the chemical formula composition of $\mathrm{CaSO}_{4} \cdot 1 / 2 \mathrm{H}_{2} \mathrm{O}$. It is derived from gypsum by heating it to about $150-180{ }^{\circ} \mathrm{C}$ :

$$
2 \mathrm{CaSO}_{4} \cdot 2 \mathrm{H}_{2} \mathrm{O} \rightarrow 2 \mathrm{CaSO}_{4} \cdot 0.5 \mathrm{H}_{2} \mathrm{O}+3 \mathrm{H}_{2} \mathrm{O} \text { (released as steam). }
$$

It is particularly popular for use in the heritage industry for repair work.

\section{Alternative Production Methods}

\subsection{Microwaves}

Microwave energy is new technology application to drying, calcining, curing and manufacturing processes requiring thermal processing. In a conventional gas or electric furnace, an object is warmed gradually by convection or radiation as heat penetrates from the outside inwards. Microwave energy, by contrast, is cold and heat is only produced when the microwave energy is absorbed by the sample. Since microwaves easily penetrate materials (with the exception of metals) they can be directed and uniformly absorbed throughout the entire volume of an object. This volumetric heating effect causes a material to heat up evenly and rapidly. The capabilities of microwave energy have opened up new opportunities in chemistry, materials science and other areas [Dagani, 1997]. In the building and construction industry these include drying of gypsum [Lindroth and Berglind, 1994], sample preparation for analyses [Figg, 1973; Strydom et al., 1999], curing of concrete [Xuequan et al., 1987] and syntheses of ceramics [Fang et al., 1996]. Very novel work done at the Materials Research Laboratory of Pennsylvania State University by various researchers illustrated the feasibility of manufacturing different types of cement using microwave technology [Fang et al., 1996; Li et al., 1998;1999;2001]. With the development of more and larger commercial microwave units, this approach might just in future become a reality on commercial scale. 


\subsection{Fluidised Bed}

Although still at pilot plant scale, several commercial companies and designs for fluidized bed kilns have been developed to produce clinker in a different configuration from the usual rotary kiln. Fluidized-bed cement kiln systems can efficiently combust low-grade coal, significantly reduce NOx emissions, and increase the heat recovery efficiency between solids and gases discharged from the process. This is due to the advantages of the fluidized-bed process, such as increased combustion and heat transfer efficiencies. It contributes to energy conservation and improves sustainability [Yuko et al., 2000]. The clinker produced is also smaller in size than those from conventional rotary kilns and require less grinding. This is clearly the next generation technology to improve sustainability in the cement production industry

\subsection{Sol-gel Technique}

The sol-gel method is based on colloid chemistry in which solid raw materials are dissolved in selected solvents under specific conditions of temperature, pressure, etc. until a homogeneous solution is formed by a hydration process. The sol is a combination of monomers of solvent-soluble or water-soluble polymers along with a precipitator. Once formed, the sol can be transformed into a gel under similar controlled conditions of temperature, pressure, etc. The sol-gels are transformed into ceramics by heating at relatively low temperatures and have better chemical and structural homogeneity than ceramics obtained by conventional solid state sintering. Materials prepared by a sol-gel process are more reactive than materials of the same compositions prepared by other methods because of their very high surface areas. One of the best known experimental methods in this area is the Pechini process to prepare high surface area materials [Pöllmann, Martin Luther University, Halle]. Although this is still in the laboratory development phase, it is a technology with much potential for full scale plant application and something that can greatly contribute to sustainability in cement manufacturing.

\section{Reduction and Elimination of Carbon Dioxide Emissions}

Ultimately the cement industry also has to address their actual carbon dioxide emissions, and not just the dilution of cement products, use of alternative fuels or increased energy efficiency and alternative cements to remain sustainable in future. Fortunately, there is a welcome move to embrace many of the new and novel technologies to deal with the actual carbon dioxide still being generated in cement manufacturing.

\subsection{Carbon Capture and Storage (CCS)}

One of the latest developments worldwide to deal with any carbon dioxide emitted from industrial processes, is carbon capture and storage. Essentially it entails a capturing of the released carbon, liquefying it under pressure and then disposing of it deep in the ocean or in a deep storage repository like a mine. It can also be used to enhance oil recovery from oil wells in the sea or on land. Although this technology is still in its infancy, it looks like a promising way to deal with a part of the greenhouse gas emission problem worldwide. 


\subsection{Biodiesel Production from Algae}

Any technology that simply captures released carbon dioxide and deposits it somewhere else, does not really address the issue of how to get rid of it. It merely reduces the size of the problem and displaces the disposal elsewhere. Lately much attention has been focused on the production of algae using carbon dioxide as a carbon source, and the subsequent production of biofuel from such algae [Extance, 2011]. An approach like this has obviously a lot of credibility to improve sustainability. In a recent announcement the company GEA NIRO claimed that it has developed a new process to convert carbon dioxide into fuel alcohol, proteins for animal feed and fertilizer for agricultural purposes by feeding the carbon dioxide to algae. The algae are then transformed to alcohol by fermentation and the residual biomatter to fertilizer. Exhausted yeast cells are then spray dried into protein powder for animal feed (Djernaes, 2011).

\subsection{Electrochemical Carbon Reduction (ECR)}

One of the most promising technologies for improving sustainability in terms of greenhouse gas (GHG) emissions, is the development of a process to reduce carbon dioxide in the presence of water to formic acid. The ERC process, the "Electrochemical Reduction of Carbon Dioxide," combines captured carbon dioxide with water to produce high value materials, such as formic acid and formate salts, which are conventionally obtained from the thermochemical processing of Fossil Fuels. However, ERC has an advantage over the established thermochemical methods for converting carbon dioxide to green chemicals, new chemicals beyond formic acid, building products and liquid fuels.

While thermochemical reactions must be driven at relatively high temperatures that are normally obtained by burning fossil fuels, ERC operates at near ambient conditions and is driven by electric energy that can be taken from an electric power grid supplied by hydro, wind, solar or nuclear energy (forms of clean or renewable energy). Formic acid is a precursor of a number of other chemicals made in various processes, especially in the pharmaceutical industry [Basile \& Ganjian, 2004; Fleischman et al., 2003].

An example of the implementation of this technology is the recently announced investment by Lafarge North America Inc. in a deal with Mantra Venture Group (Ltd) to build such a plant at one of the Lafarge group's North American cement manufacturing sites (Worldcement.com, 2010)

\subsection{Supercritical Carbon Dioxide Treatment of Concrete/Lime}

Recent research [Fabbri et al., 2009; Rimelle et al., 2008; Garcia-Gonzalez et al., 2008 and references therein; Short et al., 2004] has indicated that it is possible to increase the strength of concrete by treating it with supercritical (SCF) carbon dioxide. The carbon dioxide penetrates the concrete mixture, and reacts with the calcium hydroxide formed by the hydrated cement binder, turning it into calcium carbonate. Not only does this increase the strength of the concrete, it also makes it less permeable and therefore more durable. This could be a very beneficial use of at least some carbon dioxide, also in cases where hydraulic lime has been used as a binder. 


\subsection{Other Emissions}

Carbon dioxide is not the only environmentally harmful gas released by the cement industry. $\mathrm{SO}_{\mathrm{X}}$ and $\mathrm{NO}_{\mathrm{X}}$ compounds are also emitted and are also potentially very environmentally damaging, because they are known to cause acid rain and smog and can therefore have very damaging effects on local populations. New burner designs and lower firing temperatures are some of the methods used to curb NOx emissions. However, care should be taken to maintain the temperature high enough to destroy dioxins if any waste fuels are employed. Released $\mathrm{SO}_{\mathrm{X}}$ compounds can be reduced by the same methods employed in the power generating industry, i.e. by absorption in a lime/limestone slurry to produce FDG (flue gas desulphurised gypsum) [Srivastava et al., 2001; Ogenga et al., 2010; Lee et al., 2008].

\section{Conclusions}

So, how would an ideal, environmentally sustainable cement plant look like with the technology that is currently available? Assuming that it will still produce mostly OPC, it should start off with a large proportion of waste materials such as red mud, bottom ash and fly ash as components of the raw meal, with purified industrial gypsum as a flux to lower the burning temperature. The kiln should have at least 4-5 pre-heaters to ensure the highest energy efficiency and if appropriate, a pre-calciner should be added into the process. A substantial portion of the energy used should be derived from waste fuels, e.g. tyres, used solvents and oils, and the waste heat from the process should be recovered to generate electricity to supplement the plant's electricity requirements. The latest mills should be used to do grinding of the final product with grinding aids, and purified industrial gypsum should be used exclusively as the set-retarder in the cement produced. A part of the final OPC produced should be substituted with an inorganic mineral admixture such as fly ash, slag or metakaolin or even combinations thereof. The carbon dioxide emissions should be converted through the ERC process to starting material for further chemicals manufacturing, or buried in a deep level repository with the aid of CCS equipment.

- All these technologies have been discussed and have been proven through research, some as long ago as 3-4 decades. In many plants all over the world parts of these solutions are already implemented. One can rightly ask if the cement industry is too slow to embrace new technology and make a wholesale shift to sustainability, or if instead it prefers incremental improvements in their environmental footprint? Is it going to increase cement prices if all the technologies referred to in here are adopted? Probably, yes. Is it worth it? This author thinks so. The cement industry has to place the sustainability of the planet and the welfare of future generations high on their agenda before profit making only, and step up to their environmental responsibility. It is simply too important an industrial sector for mankind to go without, and it is possible with current technology and will power to operate in both a sustainable as well as economically profitable way. So, to answer the question posed originally, namely: Is cement and concrete production sustainable on a long term basis, and are cement producers doing enough to pursue sustainability?, the evidence cited in this paper suggest that cement and concrete production can definitely be sustainable in the long run. Judging from the possibilities to improve sustainability by adapting the raw material supply, 
modifying the production process by substituting alternative fuels and raw materials, and finally diluting the final product and treating or converting the carbon dioxide emissions, it seems that the emphasis of most cement producers are still focused on selected parts of these different possibilities, especially the final dilution and substitution of cement by various mineral admixtures. It is therefore questionable if cement producers are adapting fast enough and to a sufficient degree to exploiting all the possible options to reduce their environmental footprint.

\section{Acknowledgements}

The author gratefully acknowledges the constructive comments of Dr. L. Black from the Department of Civil Engineering, University of Leeds, UK, during the preparation of this paper.

\section{References.}

Adams, D. (12 Oct, 2007). The unheralded polluter: cement industry comes clean on its impact, Guardian. Guardian.co.uk. Retrieved on January 25, 2011 from http://www.guardian.co.uk/environment/2007/oct/12/climatechange

Anonymous. (1996). The WSZ Schwefelsäure und Zement GmbH-unique or a model for the future? ZKG 49(2), A33-A34.

Alsop, P. A., Chen, H., Jakura, A. J., McCabe, M. I., \& Tseng, H. H. (2001). The cement plant operations handbook. $3^{\text {rd }}$ Edn. International Cement Review. Germany.

Auber, J. D. L. (1981). Burning chemical wastes as synthetic fuels. Proc. Annual Meeting of the Air Pollution Control Association (APCA). Paper 81- 51.1, 74 (3).

Bakharev, T., Sanjayan, J. G., \& Cheng, Y. B. (2000). Effect of admixtures on properties of alkali-activated slag concrete, Cement \& Concrete Research, 30(9), 1367-1374. http://dx.doi.org/10.1016/S0008-8846(00)00349-5

Bakovic, S., Potgieter, J. H., De Waal D, \& Popovic L. (2006). Replacing limestone and linseed oil in the synthesis of putty. Journal of Applied Science, 6(5), 1009-1016. http://docsdrive.com/pdfs/ansinet/jas/2006/1009-1016.pdf

Basile, D. V., \& Ganjian, I. (2004). Beta-D-glucosyl and alpha-D-galactosyl Yariv reagents: syntheses from p-nitrophenyl-D-glycosides by transfer reduction using ammonium formate, Journal of Agricultural \& Food Chemistry, 52(25), 7453-7456. http://dx.doi.org/10.1021/jf0401571

Bensted, J. (1980). Early hydration behavior of Portland Cement containing boro-, citro- and desulphogypsum. Cement \& Concrete Research, 10(2), 165-171. http://dx.doi.org/10.1016/0008-8846(80)90073-3.

Beretka, J, Santoro, L, Sherman, N, \& Valenti, G. L. (1992). Synthesis and properties of low energy cements based on calciumsulfoaluminate. Proc. $9^{\text {th }}$ ICCC, New Delhi, India. Vol 1, 58-79.

Berger, S, Frizon, F, \& Joussot-Dubien, C. (2009). Formulation of caesium based and 
caesium containing geopolymers. Advances in Applied Ceramics, 108(7), 412-417. http://dx.doi.org/10.1179/174367609X422072

Black L, Purnell P, Hill, J. (2010). Current themes in cement research. Advances in Applied Ceramics 109(5), 253-259. http://dx.doi.org/10.1179/174367510X12714358363805.

Bolio-Arcea H, Glasser FG. (1998). $\mathrm{ZnO}$ in cement clinkering: Part 1. Systems $\mathrm{CaO}-\mathrm{ZnO}-\mathrm{Al}_{2} \mathrm{O}_{3}$ and $\mathrm{CaO}-\mathrm{ZnO}-\mathrm{Fe}_{2} \mathrm{O}_{3}$. Advances in Cement Research 10(1), 25-32. http://dx.doi.org/10.1680/adcr.2000.12.4.173

Bye, GC. (1990). Portland Cement. $2^{\text {nd }}$ Edn. Thomas Telford Limited. London, UK

Canpolat FK, Yilmaz MM, Köse MM, Sümer M, Yurdusev MA (2004). Use of zeolite, coal bottom ash and fly ash as replacement materials in cement production. Cement \& Concrete Research 34, 731-736. http://dx.doi.org/10.1016/S0008-8846(03)00063-2.

Chandra S. (1996). "Red Mud Utilization". Waste materials used in concrete manufacturing. 292-295. ISBN 9780815513933.

Cotea I, Romanescu A, Dumitrescu C. (1986). Researches concerning the harmful components elimination from phosphogypsum for using it as a cement setting time regulator. Proc. $8^{\text {th }}$ ICCC (International Chemistry of Cement Conference), Rio de Janeiro, Vol. VI, 430-433

Corinaldesi V. (2010). Mechanical and elastic behaviour of concretes made of recycled-concrete coarse aggregates. Construction \& Building Materials 24 (9), 1616-1620. http://dx.doi.org/10.1016/j.conbuildmat.2010.02.031.

Curcio F, Deangelis BA, Pagliolico S. (1998). Metakaolin as a pozzolanic microfiller for high-performance mortars. Cement \& Concrete Research 28(6), 803-809 http://dx.doi.org/10.1016/S0008-8846(98)00045-3.

Dagani R. (Febr. 1997). Molecular magic with microwaves. Chemical \& Engineering News $26-33$

Darweesh, HHM. (2001). Low temperature portland cement clinker based on alkaline basaltoid and composite mineralizers. Industrial Ceramics 21(1), 5-8

Davidovits J. (1989). Geopolymers and geopolymeric new materials. Journal of Thermal Analysis and Calorimetry 35(2), 429-441. http://dx.doi.org/10.1007/BF01904446.

De Silva PS, Glasser FP. (1992). Pozzolanic activity of Metakaolin. Advances in Cement Research $4(16)$, 167-178. http://www.csa.com/partners/viewrecord.php?requester=gs\&collection=TRD\&recid=CA731 0089WC.

Djelal C, Vanhove Y, De Caro P, Magnin A. (2002). Role of demoulding agents during self-compacting concrete casting in formwork. Material Structures 35(252), 470-476

Djernaes RZ. (2011). GEA Niro initiative converts $\mathrm{CO}_{2}$ into fuel and animal feed. Chemical 
Technology, February: 11

Duxson P, Fernandez-Jimenez A, Provis JL, Lukey GC, Palomo A, van Deventer JSJ. (2007). Geopolymer technology: the current state of the art. Journal of Materials Science 42(9), 2917-2933. http://dx.doi.org/10.1007/s10853-006-0637-z.

El-Didamony H, Rahman AA, Nassar F, Saraya, M. (2010). Effect of basalt on the burnability of raw meal of Portland cement clinker. Indian Journal of Engineering and Materials Science 17(4), 282-288. http://hdl.handle.net/123456789/10069.

EN 197-1. (2000). Cement Composition, specifications and conformity criteria for common cements.

Extance A. (2011). Rehabilitating captured $\mathrm{CO}_{2}$. Chemistry World 8(2), 40-43

Fabbri A, Corvisier J, Schubnel A, Brunet F, Goffe B, Rimmele G, Barlet-Gouedard V. (2009). Effect of carbonation on the hydro-mechanical properties of Portland cements. $\begin{array}{llll}\text { Cement } \quad \text { C } \quad \text { Concrete } & \text { Research (12), 156-1163 }\end{array}$ http://dx.doi.org/10.1016/j.cemconres.2009.07.028.

Fang Y, Roy DM, Roy, R. (1996a). Microwave clinkering of ordinary and colored Portland cements. Cement \& Concrete Research 26(1), 41-47. http://dx.doi.org/10.1016/0008-8846(95)00183-2.

Fang Y, Chen Y, Silsbee MR, Roy DM. (1996b). Microwave sintering of fly ash. Materials Letters 27, 159-159. http://dx.doi.org/10.1016/0008-8846(95)00183-2.

Figg J. (1973). Microwave heating in concrete analysis. Journal of Applied Chemistry and Biotechnology 24, 143 - 155. http://dx.doi.org/10.1002/jctb.2720240306

Fleischman SG, Kuduva SS, McMahon JA, Moulton B, Walsh RDB, Rodriguez-Hornedo N, Zaworotko MJ. (2003). Crystal engineering of the composition of pharmaceutical phases: Multiple-component crystalline solids involving carbamazepine. Crystal Growth \& Design 3(6), 909-919. http://dx.doi.org/10.1021/cg034035x.

Flowers AD, Linderman, K. (2003). Hazardous waste disposal: A waste-fuel blending

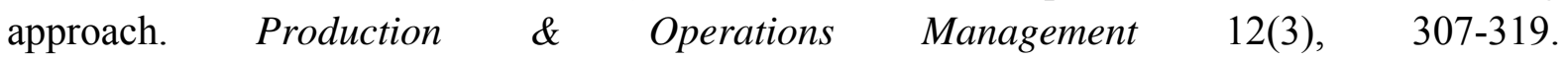
http://dx.doi.org/10.1111/j.1937-5956.2003.tb00205.x.

Garcia-Gonzalez CA, el Grouh N, Hidalgo A, Fraile J, Lopez-Periago AM, Andrade C, Domingo C. (2008). New insights on the use of supercritical carbon dioxide for the accelerated carbonation of cement pastes. Journal of Supercritical Fluid, 43(3), 500-509. http://dx.doi.org/10.1016/j.supflu.2007.07.018.

Hanson CM. (1995). Concrete: The advanced industrial material of the $21^{\text {st }}$ century. Metallurgical \& Materials Transactions A, 26A, 1321-1341. http://dx.doi.org/10.1007/BF02647584

Helmy IM. (2003). Utilization of some waste products as mineralizers in the formation of Portland cement clinker. Industrial Ceramics 23(1), 41-45. 
Hendriks CA, Worrell E, De Jager D, Blok K, Riemer P. (2004). Emission Reduction of Greenhouse Gases from the Cement Industry. Conference on Greenhouse Gas Control Technologies, Paper, 1-11 Available on: http://www.ieagreen.org.uk/prhgt42.htm

Idir R, Cyr M, Tagnit-Hamou A. (2010). Use of fine glass as ASR inhibitor in glass aggregate $\begin{array}{llll}\text { mortars. } \quad \text { Construction } \& \quad \text { Building } & \text { Materials 24(7), }\end{array}$ http://dx.doi.org/10.1016/j.conbuildmat.2009.12.030.

Jeknavorian AA, Barry EF, Serafin, F. (1998). Determination of grinding aids in Portland cement by pyrolysis gas chromatography-mass spectrometry. Cement \& Concrete Research 28(9), 1335-1345. http://dx.doi.org/10.1016/S0008-8846(98)00109-4.

Jolicoeur C, Simard MA. (1998). Chemical admixture-cement interactions: Phenomenology and physico-chemical concepts. Cement \& Concrete Composites 20(2-3), 87-101. http://dx.doi.org/10.1016/S0958-9465(97)00062-0.

Johansen V, Kouznetsova TV. (1992). Clinker formation and new processes. Proc. 9th ICCC, New Delhi, India, Vol. 1, 125-52

Kacimi L, Simon-Masseron A, Ghomari A, Derriche, Z. (2006). Reduction of clinkerization temperature by using phosphogypsum, Journal of Hazardous Materials 137(1), 129-137. http://dx.doi.org/10.1016/j.jhazmat.2005.12.053

Kakali G, Tsivilis S, Tsialtas A. (1998). Hydration of ordinary Portland cements made from raw mix containing transition element oxides. Cement \& Concrete Research 28(3), 335-340. http://dx.doi.org/10.1016/S0008-8846(97)00250-0.

Kendall K, Howard AJ, Birchall JD, Pratt PL. (1983). The relation between porosity, microstructure and strength, and the approach to advanced cement-based materials. Philosophical Transactions of the Royal Society London, A310, 139-153

Kohlhaas A, Laban AO. (1983). Cement Handbook (2 ${ }^{\text {nd }}$ Edn). Bauverlag GmbH. Wiesbaden und Berlin, Germany.

Komnitsas K, Zaharaki D. (2007). Geopolymerisation: A review and prospects for the minerals industry. Minerals Engineering 20(14), 1261-1277. http://dx.doi.org/10.1016/j.mineng.2007.07.011

Kruger JE. (2002). Origin, history and properties of South African fly ash and Portland fly ash cements. South African Coal Ash Association (SACAA), Guide 2,2

Kumar S, Kumar R, Mehrotra SP. (2010). Influence of granulated blast furnace slag on the reaction, structure and properties of fly ash based geopolymer. Journal of Materials Science 45(3), 607-615. http://dx.doi.org/10.1007/s10853-009-3934-5

Kwon WT, Kim YP, Kim Y, Kim SR, Bae SY. (2006). Effect of pair-mineralizer on the reaction of alite and calcium langbeinite formation. Materials Science Forum 510-511, $622-625$

Lawrence CD. (1998). The production of low-energy cements. In: Hewlett PC, editor. Lea's 
Chemistry of Cement and Concrete. 4th Ed. London: Arnold: 421-470.

Lee KT, Tan KC, Dahlan I, Mohamed, AR (2008). Development of kinetic model for the reaction between $\mathrm{SO}_{2} / \mathrm{NO}$ and coal fly ash/CaO/CaSO 4 sorbent. Fuel 87(10-11), 2223-2228. http://dx.doi.org/10.1016/j.fuel.2007.09.008.

Leemann A, Winnefeld F. (2007). The effect of viscosity modifying agents on mortar and concrete. Cement \& Concrete Composites 29(5), 341-349. http://dx.doi.org/10.1016/j.cemconcomp.2007.01.004

Li C Z, Feng N Q, Li Y D, Chen RJ. (2005). Effects of polyethlene oxide chains on the performance of polycarboxylate-type water-reducers. Cement \& Concrete Research, 35(5), 867-873. http://dx.doi.org/10.1016/j.cemconres.2004.04.031.

Li H, Silsbee MR, Cheng J, Agrawal DK. (1999). Formation and hydration of $\mathrm{C}_{3} \mathrm{~S}$ prepared by microwave and comparison with the conventional method. Cement \& Concrete Research 29(10), 1611-1618. http://dx.doi.org/10.1016/S0008-8846(99)00145-3.

Li, H, Silsbee MR, Cheng J, Agrawal DK. (1998). Microwave preparation of tricalcium silicate by microwave sintering. Presentation at the $100^{\text {th }}$ American Ceramic Society Annual Meeting, Ohio, USA

Li H, Agrawal DK, Cheng J, Silsbee MR. (2001). Microwave sintering of sulphoalumina cement with utility waste. Cement \& Concrete Research 31, 1257-1261. http://dx.doi.org/10.1016/S0008-8846(01)00579-8.

Lindroth DP, Berglind WR. (Febr. 1994). Microwave drying of the flue-gas desulphurized gypsum. Environmental \& Minerals Journal 34-38.

Maeng JR. (1996). Grinding granulated blastfurnance slag in the roller mill at Tong Yang Cement in South Korea. ZKG 49(7), 392-399.

Marinkovic S, Radonjanin V, Malesev M, Ignjatovic I. (2010). Comparative environmental assessment of natural and recycled aggregate concrete. Waste Management 30(11), 2255-2264. http://dx.doi.org/10.1016/j.wasman.2010.04.012.

Meyer C. (2009). The greening of the concrete industry. Cement \& Concrete Composites 31, 601-605. http://dx.doi.org/10.1016/j.cemconcomp.2008.12.010.

Mourninghan RE, Peters JA, Branscome RM. (1985). Effects of burning hazardous wastes in cement kilns on conventional pollutant emissions. Proc. Annual Meeting of APCA, Paper 85-68.1, 78 (5).

Mozgawa W, Deja, J. (2009). Spectroscopic studies of alkaline activated slag geopolymers. $\begin{array}{llll}\text { Journal of } \quad \text { Molecular } & \text { Structure } & \text { 924-26, }\end{array}$ http://dx.doi.org/10.1016/j.molstruc.2008.12.026.

Mullick AK. (1992). Advances in Portland Cements and utilization of industrial wastes:towards sustainable development. Proc. $9^{\text {th }}$ ICCC, New Delhi, India. Vol 1, 58-79 
Murat M, Sorrentino F. (1996). Effects of large additions of Cd, Pb, Cr, $\mathrm{Zn}$ to cement raw meal on the composition and the properties of the clinker and the cement. Cement \& Concrete Research 26(3), 377-385. http://dx.doi.org/10.1016/S0008-8846(96)85025-3.

Ogenga DO, Mbarawa MM, Lee KT, Mohamed AR, Dahlan I. (2010). Sulphur dioxide removal using South African limestone/siliceous materials. Fuel 89(9), 2549-2555. http://dx.doi.org/10.1016/j.fuel.2010.04.029.

Palomo A, Grutzeck MW, Blanco MT. (1999). Alkali-activated fly ashes - A cement for the

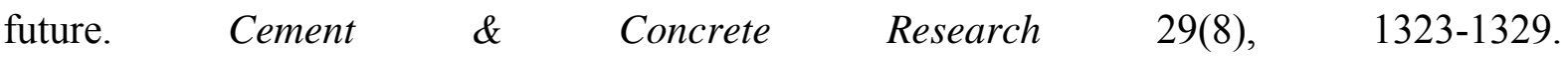
http://dx.doi.org/10.1016/S0008-8846(98)00243-9

Phair JW. (2006). Green chemistry for sustainable cement production and use. Green Chemistry 8(9), 763-780. http://dx.doi.org/10.1002/chin.200702270

Pöllmann H. (2010). Martin Luther University, Halle, Germany. Available at http://www.geologie.uni-halle.de/igw/mingeo accessed Dec 2010

Potgieter JH. (1997). High temperature chemistry in a cement clinker kiln. South African Journal of Chemistry 50(3), 111-114

Potgieter JH, Potgieter SS. (2000). An evaluation of various physical and chemical treatments to render phosphogypsum suitable as a set-retarder for cement. Proc. $6^{\text {th }}$ Int. Conf. Natural \& Synthetic Gypsum, Toronto, Canada.

Potgieter JH, Horne KA, Potgieter SS, Wirth W. (2002). An evaluation of the incorporation of a Titanium Dioxide producer's waste material in Portland cement clinker. Materials Letters 57, 157-163. http://dx.doi.org/10.1016/S0167-577X(02)00723-1

Potgieter JH, Potgieter SS, McCrindle RI, Strydom CA. (2003). An investigation into the effect of various chemical and physical treatments of a South African phosphogypsum to render it suitable as a set-retarder for cement. Cement \& Concrete Research 33(8), 1223-1227. http://dx.doi.org/10.1016/S0008-8846(03)00036-X.

Potgieter-Vermaak SS, Potgieter JH. (2006). Metakaolin as an extender in South African Cement. Journal of Materials for Civil Engineering 18(4), 619-623. http://ascelibrary.org/doi/abs/10.1061/(ASCE)0899-1561(2006)18,4(619).

Potgieter JH, Love A. (2010). Die effek van statistiese analitiese metingsvariasies op aanlegkontroleparameters en koste in sementvervaardiging: "n gevallestudie (The effect of statistical analytical measurement variations on the plant control parameters and production costs in cement manufacturing-a case study). South African Journal of Science and Technology 29(2), 66-76. http://www.satnt.ac.za/index.php/satnt/article/view/10/10.

Popescu CD, Muntean M, Sharp JH. (2003). Industrial trial production of low energy belite cement. Cement \& Concrete Composites 25, 689-693. http://dx.doi.org/10.1016/S0958-9465(02)00097-5.

Provis J L, Yong CZ, Duxson P, van Deventer JSJ. (2009). Correlating mechanical and 
thermal properties of sodium silicate-fly ash geopolymers. Colloids \& Surfaces A 336 (1-3), 57-63. http://dx.doi.org/10.1016/j.colsurfa.2008.11.019.

Rajabipour F, Maraghechi H, Fischer G. (2010). Investigating the Alkali-Silica Reaction of Recycled Glass Aggregates in Concrete Materials. Journal of Materials for Civil Engineering 22(12),

1201-1208. http://ascelibrary.org/doi/abs/10.1061/\%28ASCE\%29MT.1943-5533.0000126.

Rimmele G, Barlet-Gouedard V, Porcherie O, Goffe B, Brunet F. (2008). Heterogeneous porosity distribution in Portland cement exposed to $\mathrm{CO}_{2}$-rich fluids. Cement \& Concrete Research 38(8-9), 1038 - 1048. http://dx.doi.org/10.1016/j.cemconres.2008.03.022.

Rodrigues FA, Joekes I. (2010). Cement Industry: sustainability, challenges and perspectives. Environmental Chemistry Letters. http://dx.doi.org/10.1007/s10311-010-0302-2

Roy D. (1999). Alkali-activated cements - Opportunities and challenges. Cement \& Concrete Research 29(2), 249 - 254. http://dx.doi.org/10.1016/S0008-8846(98)00093-3.

Sahu S, Majling J. (1994). Preparation of sulpho-aluminate belite cement from fly ash. $\begin{array}{lllll}\text { Cement } \& \quad \text { Concrete } \quad \text { Research } & \text { 1065-1072. }\end{array}$ http://dx.doi.org/10.1016/0008-8846(94)90030-2.

Santos RS, Rodrigues RA, Segre N, Joekes I. (1999). Macro-defect free cements: influence of poly (vinyl alcohol), cement type and silica fume. Cement \& Concrete Research 28, 747-751. http://dx.doi.org/10.1016/S0008-8846(98)00029-5.

Schmitz C. (2006). "Red Mud Disposal". Handbook of aluminium recycling. 18-19. ISBN 9783802729362.

Sharp JH, Lawrence CD, Yang R. (1999). Calcium sulfoaluminate cements-low energy cements special cements or what? Advances in Cement Research 11, 3-13. http://dx.doi.org/10.1680/adcr.2010.22.4.195.

Shen L, Cheng S, Gunson AJ, Wan H. (2005). Urbanisation, sustainability and the utilization of energy and mineral resources in China. Cities 22, 287-302. http://dx.doi.org/10.1016/j.cities.2005.05.007.

Shibamoto T, Yasuhara A, Katami T. (2007). Dioxin Formation from Waste Incineration. Reviews of Environmental Contamination and Toxicology 190, 1-41. http://dx.doi.org/10.1007/978-0-387-36903.

Shirasaka T, Hanehara S, Uchikawa, H. (1996). Influence of six minor and trace elements in raw material on the composition and structure of clinker. World Cement 27(3), 102-115. http://dx.doi.org/35400004482999.0130

Short NR, Brough AR, Seneviratne AMG, Page CL, Purnell P. (2004). Preliminary investigations of the fine pore structure of super-critically carbonated cement pastes; Journal $\begin{array}{llll}\text { of } & \text { Materials } & \text { Science } & 39,\end{array}$ http://dx.doi.org/10.1023/B:JMSC.0000040076.42260.cb 
Singh M, Reshi SS, Taneja CA. (1984). Rendering phosphogypsum suitable for plaster manufacturing. Indian Journal of Technology 22, 22-28

Singh M, Garg M, Reshi SS. (1993). Purifying phosphogypsum for cement manufacture. $\begin{array}{lllll}\text { Construction } \quad \& \quad \text { Building } & \text { Materials } & 7(1), & 3-7 .\end{array}$ http://dx.doi.org/10.1016/0950-0618(93)90018-8.

Srivastava RK, Jozewicz W, Singer C. (2001). $\mathrm{SO}_{2}$ scrubbing technologies: A review. Environmental Progress 20(4), 219-227. http://www.aiche.org/publications/tocs/issuedtl.asp, [NET]. 03/15/2001.

Stavraki A, Wilson K, Ritchie A. (2005). Update on solid waste derived fuels for use in cement kilns - An international perspective. Science Report SC030168/SR2 Environment Agency, Rio House, Waterside Drive, Aztec West, Almondsbury, Bristol, BS32 4UD, UK. http://publications.environment-agency.gov.uk/PDF/SCHO0106BJZN-E-E.pdf

Stoiber W. (2003). Communition technology and energy consumption, part 1. Cement International 1(2), 45 - 52

Strydom CA, Potgieter JH, Mhlongo WJ, Masina C. (1999). Extraction of Free lime from clinkers using microwave energy. World Cement 30(11), 101-104

Sutho K, Sakae K, Hirose T, Takahashi H, Mitakoshi, T. (1996). Destruction of CFCs in cement kilns. World Cement 27(5), 64-75

Tamas, F.D. (1992). The use of waste fuels in the cement industry. Proc. $9^{\text {th }}$ ICCC, New Delhi, India, Vol 6, 77-87

Taylor, H.F.W. (1997). Cement Chemistry, Thomas Telford Publishers, UK.

Theisen K. (1993). Estimation of cement clinker grindability. Proceedings of the fifteenth International conference on Cement Microscopy, 17-20

Toutanji H, Delatte N, Aggoun S, Duval R, Danson, A. (2004). Effect of supplementary cementitious materials on the compressive strength and durability of short-term cured concrete. Cement \& Concrete Research 34(2), 311 - 319. http://dx.doi.org/10.1016/j.cemconres.2003.08.017.

Uchikawa H, Obana H. (1995). Ecocement-frontier of recycling of urban composite wastes. World Cement 26(11), 33-40

Wang CF, Li JS, Wang LJ, Sun XY. (2008). Influence of $\mathrm{NaOH}$ concentrations on synthesis of pure-form zeolite A from fly ash using two-stage method. Journal of Hazardous Materials . 155, 58-64. http://dx.doi.org/10.1016/j.jhazmat.2007.11.028,

Weitzmann L. (1983). Cement kilns as hazardous waste incinerators. Environmental Progress 2(1), 10-14. http://dx.doi.org/10.1002/ep.670020106

Wirsching F. (1978). Gypsum, in Ullmann's Encyclopedia of Chemical Technology, Vol. 12. Verlag Chemie, GmbH, Germany: 1-25. 
Xuequan W, Jianbgo D, Mingshu, J. (1987). Microwave curing technique in concrete manufacture. Cement \& Concrete Research 17, 205-210. http://dx.doi.org/10.1016/0008-8846(87)90103-7.

Yao ZT, Xia MS, Ye Y, Zhang L. (2009). Synthesis of zeolite Li-ABW from fly ash by fusion method. Journal of Hazardous Materials 170, 639-644. http://dx.doi.org/10.1016/j.jhazmat.2009.05.018.

Yuko T, Ikabata T, Akiyama T, Yamamoto T, Kurumada N. (2000). New clinker formation process by the fluidized bed kiln system, Cement \& Concrete Research 30, 1113-1120. http://dx.doi.org/10.1016/S0008-8846(00)00274-X.

Zawawi R, Banfill PFG. (2006). Effect of burning conditions on properties of artificial hydraulic lime mortar obtained from limestone and siliceous waste materials. Advances in Applied Ceramics 105(4), 175-178. http://dx.doi.org/10.1179/174367606X121295

Zhang J, Provis JL, Feng D, van Deventer, JSJ. (2008). The role of sulfide in the immobilization of $\mathrm{Cr}(\mathrm{VI})$ in fly ash geopolymers. Cement \& Concrete Research 38(5), 681-688. http://dx.doi.org/10.1016/j.cemconres.2008.01.006.

Zuda L, Drchalova J, Rovnanik P, Bayer P, Kersner Z, Cerny R. (2010). Alkali-activated aluminosilicate composite with heat-resistant lightweight aggregates exposed to high temperatures: Mechanical and water transport properties. Cement \& Concrete Composites 32(2), 157-163. http://dx.doi.org/10.1016/j.cemconcomp.2009.11.009.

Zur Strassen H. (1957). The theoretical heat requirement for cement burning. ZKG, 10, 1.

\section{Copyright Disclaimer}

Copyright reserved by the author(s).

This article is an open-access article distributed under the terms and conditions of the Creative Commons Attribution license (http://creativecommons.org/licenses/by/3.0/). 